Papers and Proceedings of the Royal Society of Tasmania, Volume 118, 1984

(ms. received 10.VI.1983)

\title{
TASMANIAN HIGH MOUNTAIN VEGETATION I I - ROCKY HILL AND PYRAMID MOUNTAIN
}

by J.B. Kirkpatrick

Department of Geography, University of Tasmania

(with two tables, three text-figures and four plates)

ABSTRACT

KIRKPATRICK, J.B., 1984 (31 viii): Tasmanian high mountain vegetation II - Rocky Hill and

Pyramid Mountain. Pap. Proc. R. Soc. Tasm., 118: 5-20, pls 1-4.

https://doi.org/10.26749/rstpp.118.5 IsSN 0080-4703. Department of Geography,

University of Tasmania, Hobart, Tasmania, Australia.

Rocky Hill and Pyramid Mountain are composed of horizontally bedded Permian to Upper Carboniferous sedimentary rocks, the nature of which has encouraged the development of fjaeldmark and nonsorted stone steps and stripes. Buried Athrotaxis logs in the present alpine zone, the patterns of distribution of fire-susceptible species and other evidence suggest that the area has been subject to at least two severe and extensive fires, which have resulted in landscape instability. Nevertheless, the present vegetation of the area is varied, lacking only deciduous heath and tussock grassland of the alpine subformations and having a full range from sedgeland to closed-forest in the subalpine vegetation. The species composition of the vegetation of the two mountains is most similar to that of Cradle Mountain.

\section{INTRODUCTION}

The Tasmanian high mountains possess varied floras and vegetation complexes, these variations most strongly relating to precipitation and soil characteristics (Kirkpatrick $1980,1982,1983$ ). Most of the mountains with alpine vegetation (sensu Kirkpatrick 1982) consist of dolerite or highly siliceous quartzites and quartzitic conglomerates. However, there is a small number of mountains formed of horizontally bedded Permian to Upper Carboniferous sediments, on which there are concentrated the Tasmanian fjaeldmarks (Kirkpatrick \& Harwood 1980, Kirkpatrick 1983). This paper provides a description of the fjaeldmarks and other vegetation of two of these sedimentary mountains, Rocky Hill (1160 m) and Pyramid Mountain $(1250 \mathrm{~m})$, both located in the wilderness between Lake St Clair and Queenstown (fig. 1). No nearby climatic data are available but mean annual precipitation certainly exceeds $2000 \mathrm{~mm}$.

METHODS

All higher plant species observed were noted and/or collected during a field trip in February 1983. Nomenclature follows Curtis (1963, 1967, 1979), Curtis \& Morris (1975), Curtis \& Stones (1978) and Willis (1970) with the latest publication having precedence. Authors are given in table l (tables after references) wherever nomenclature cannot follow these authorities. Specimens are held in the Herbarium of the Tasmanian Museum and Art Gallery.

Notes were made of the occurrence and environmental relationships of species, vegetation structure and periglacial landforms. Twenty-nine $10 \times 10 \mathrm{~m}$ quadrats were $10 \mathrm{cated}$ in order to encompass the major part of the variation in alpine vegetation. All higher plant species, the dominant species, the vegetation structure and details of the environment of each quadrat were recorded.

The vegetation was mapped from field observation and interpretation of 1979 panchromatic vertical aerial photographs. Fire boundaries were obtained from earlier photographs and field evidence. 


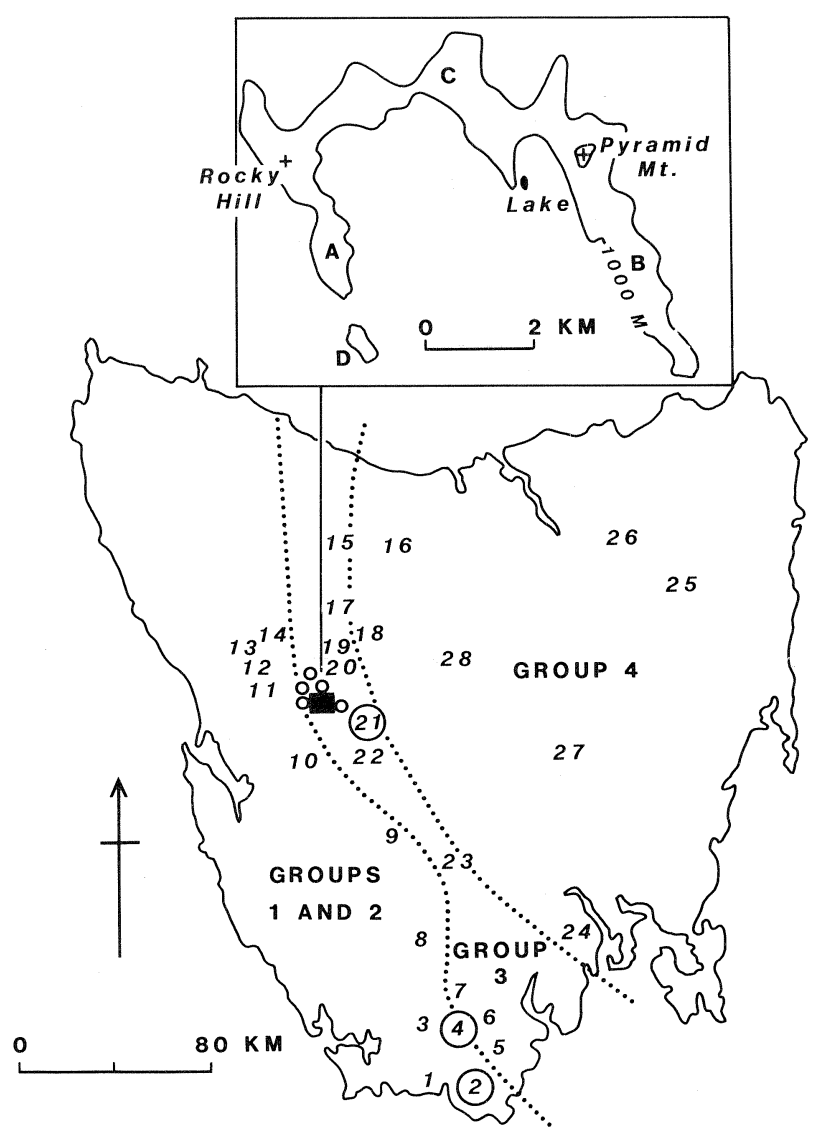

FIG. 1 - Locations of study area, the mountain flora classification of

Kirkpatrick (1982), and

known locations of nonsorted stone stripes and steps

(large and small circles). Mountain codes:

1 Ironbound Range

2 Southern Range (including Mt La Perouse)

3 Eastern Arthur Range

4 Mt Bobs/Boomerang

5 Adamsons Peak

6 Hartz Mountains

7 Mt Picton

8 Mt Anne

9 Denison Range

10 Frenchmans Cap

11 Mt Sedgwick

12 Tynda11 Range

13 Mt Read

14 Mt Murchison

15 Black Bluff

16 Mt Roland

17 Cradle Mt-Barn Bluff

18 Mt Oakleigh

19 Mt Ossa/Pelion East

20 Walled Mountain

21 Mt Rufus

22 Mt King William

23 Mt Field

24 Mt We11ington

25 Ben Lomond

26 Mt Barrow

27 Table Mountain

28 Central Plateau.

Species associations in the alpine vegetation were discriminated using the matrixresorting methods described and justified in Kirkpatrick (1980). Structural terminology follows Kirkpatrick (1983) for alpine vegetation and Specht (1974) for other vegetation.

\section{RESULTS}

\section{Floristic Relationships}

Rocky Hill and Pyramid Mountain have highly similar alpine floras (fig. 2, table 1), that of Pyramid Mountain largely being a subset of the richer Rocky Hill flora. Pyramid kiountain lacks site conditions suitable for many of the species found in bolster heath and short alpine herbfield. It also lacks the areas of quartzite found at the lowest alpine elevations on Rocky Hill, within which were confined characteristically western species such as Isophysis tasmanica, Eucalyptus vermicosa and Monotoca submutica.

Both mountains belong in group 3 of Kirkpatrick (1982), the central group of floras which extends from Black Bluff in the north to Adamsons Peak in the south (fig. 1), their closest affinities being with Cradle Mountain (fig. 2). The mountains with alpine floras 


\section{J.B. Kirkpatrick}

least similar to those of Pyramid Mountain and Rocky Hill are those in the West Coast Range and the far east of the State, the floristic extremes within Tasmania.

\section{Species Associations}

Several strong groups of species with similar distributions in the alpine vegetation of the study area are evident in table 2. The most widespread of these associations was that between Orites revoluta, Olearia ledifolia, Epacris serpyllifolia, Poa gunni, Fuphrasia striata, Pentachondra pumila and Helichrysum milliganii. The association Richea sprengelioides-Senecio pectinatusExocarpos humifusus-Helichrysum backhousiiBellendena montana was found throughout the fjaeldmark vegetation, while the associations Senecio Zeptocarpus-Agrostis venusta-Drapetes tasmanica-Plantago tasmanica and Coprosma nitida-Deyeuxia monticola-Dichosciadeum ranunculaceum were confined to the fjaeldmark on the steepest slopes of Pyramid Mountain.

The strong association Microcachrys tetragonaCyathodes dealbata-Erigeron stellatus-Carpha alpina occurs in the gentler-sloping fjaeld-

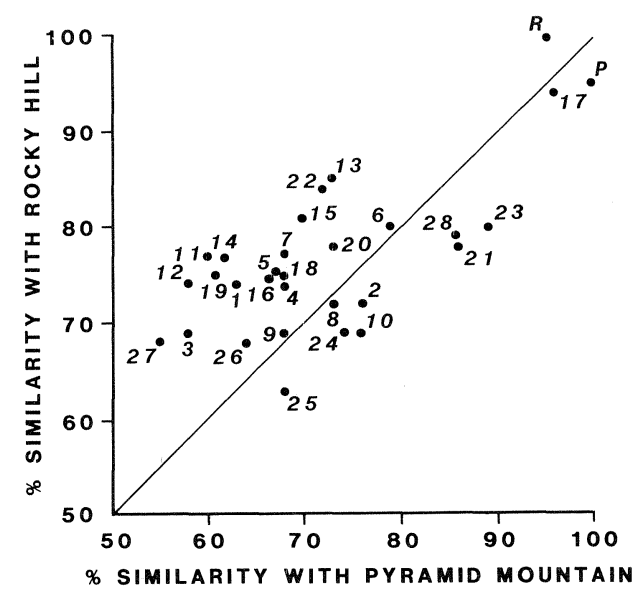

FIG. 2 - Floristic similarities between Pyramid Mountain, Rocky Hill and other Tasmanian mountains, shown in figure 1.

mark and the vegetation with complete cover on other sampled alpine sites. The more poorly drained sites on both mountains were characterized by the association Ewartia meredithaeSprengelia incarnata-Baeckea gunniana-Oreobolus pumilio-Danthonia pauciflora. The weak association Drosera arcturi-Gleichenia alpina-Microlaena tasmanica-Actinotus suffocataDonatia novae-zelandiae-Anemone crassifolia was confined to some of the poorly-drained sites outside Pyramid Mountain.

Few of the above associations are similar to those revealed for Mt Picton, the Eastern Arthur Range, Mt Bobs and the Boomerang by similar analyses in Kirkpatrick (1980) and Kirkpatrick \& Harwood (1980) despite these mountains having a high proportion of their alpine species in common with Rocky Hill and Pyramid Mountain (fig. 2). The degree of mountain specificity in Tasmanian alpine plant associations can only ultimately be tested by a statewide analysis of quadrat/releve data.

\section{Fjaeldmark}

Fjaeldmark is found in the study area of slopes varying from $1: 1$ to $1: 3$. The vegetation type is confined to the western slopes and the tops of hills and peaks, the slopes sheltered from the prevailing winds invariably possessing complete plant cover (fig. 3).

The flat-topped hills A and B (fig. 1) support a fjaeldmark in which there is clear evidence of the migration of individual shrubs in the same manner as has been recorded for the metasediment ridges at Kosciusko (Barrow et al. 1968) and the Boomerang (Kirkpatrick \& Harwood 1980). All shrub species occurring within this fjaeldmark (Epacris serpyzlifolia, Richea sprengelioides, Microcachrys tetragona, Orites revoluta, Leptospermum mupestre, Cyathodes petiolaris, Cyathodes dealbata, Pentachondra pumila) were examined and proved to layer and to have dead stems on their windward side. The rhizomatous herbs Erigeron stellatus, Helichrysum milliganii, Senecio pectinatus, Poa gunnii and Oreobolus oligocephalus also occurred in this fjaeldmark. The shrubs do not have the even distribution that occurs at Kosciusko as the uniformity of the substrate is broken by occasional bedrock outcrops, creating a tendency towards lineation. However, individual shrubs are well separated within these weak lines, their past movements being marked by strings of dead stems which are abraded flat to windward. 


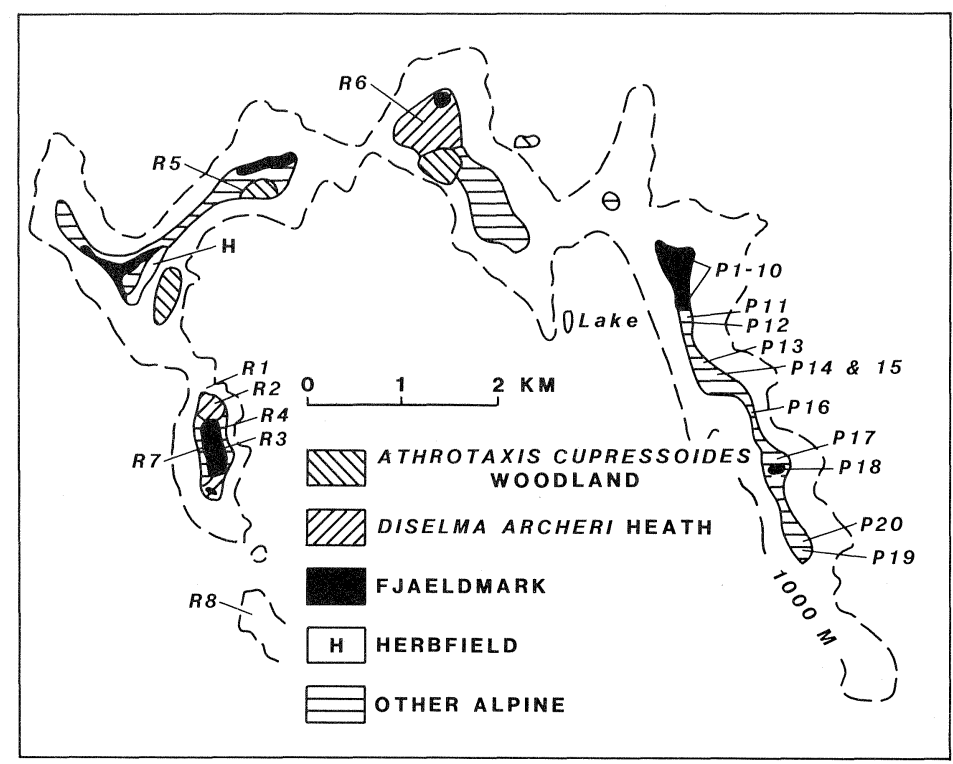

FIG.3 - The distributions of alpine plant communities and Athrotaxis cupressoides woodland.

Nonsorted stone steps (Washburn 1979) occur on the slightly steeper slopes surrounding the stone pavements occupied by migrating shrubs (plate 1). They are also found on Rocky Hill and on the southern aspect of the aptly named Pyramid Mountain. At Pyramid Mountain the nonsorted stone steps imperceptibly change to nonsorted stone stripes, the transition occurring at a general slope angle of approximately $8^{\circ}$. The steps and stripes have an alignment independent of the underlying rock stratigraphy. The treads of both steps and stripes support only an extremely sparse cover of Drapetes tasmanica, Senecio pectinatus and, occasional1y, Dichosciadeum ranunculaceum. The risers are fully vegetated with herbs such as Senecio Zeptocarous and Mizligania densiflora sheltering under 0.2-0.5 m tal1 tangled shrubs (plate 2). On the Pyramid Mountain steps and stripes, the risers vary in height from 1.00 to $1.75 \mathrm{~m}$ and in width from 1.50 to $3.0 \mathrm{~m}$, while the treads vary in width from 4 to $9 \mathrm{~m}$. On the stone stripes the treads have their maximum steepness parallel to the risers, this slope being typically in the range $15-25^{\circ}$. The material in the treads consists of small shattered rock particles over a mixture of rock particles and fines. Vegetation traps rock and soil particles, creating the steep (25-40 ) risers. Particles are moved downhill by water and by gravitational movement after needle ice disruption. Finer particles are transported uphill by the strong prevailing westerly winds until trapped in the riser vegetation.

On hills A and C (fig. 1) flat, bare areas have developed amongst Diselma archeri coniferous heath. These areas are occupied by pools of water after heavy or prolonged rain, the alternation between inundation and exposure excluding higher plant growth. Small lunette dunes form to the leeward of these features (plate 3) which show evidence of erosion rather than deposition on their other margins.

\section{Snow Patch Vegetation}

A distinct vegetation is found in those situations below the leeward edges of plateaus and peaks where snow tends to accumulate and be protected from wind ablation. Steep, slightly stepped east-facing slopes develop a characteristic vegetation sequence (table 2 , 


\section{J.B. Kirkpatrick}

R4 and P20), probably related to snow patch duration, movement and melting patterns. At the break of slope between the plateau and the snow patch there is a dense growth of metre tall shrubs with their foliage extended away from the prevailing winds and pruned to the general height of the nearby plateau. Leptospermum rupestre is the dominant species in this zone. On the steep slopes immediately below the $L$. rupestre heath there is a mat heath dominated by Cyathodes dealbata and Pentachondra pumila.

Microcachrys tetragona forms a prostrate coniferous heath immediately below the mat heath and in turn gives way to a heath in which Richea sprengelioides and Helichrysum backhousii are the most prominent species as the slope gets successively gentler and the snow lie more prolonged. Richea sprengelioides, $H$. backhousii and $M$. tetragona have a characteristic growth habit in these snow patch situations, their stems extending down hill, and being upright only at their extremes, thus incurring minimum damage with snow movement. Nothofagus cunninghamii scrub is found below the snow patch vegetation.

The largest snow patch in the study area occurs along the base of the uppermost cliffs on Rocky Hill. The southernmost part of this patch is a MizZigania densiflora tall alpine herbfield. The northern part of the patch supports a short alpine herbfield dominated in wet areas by Ranunculus nanus and Juncus antarcticus. Short alpine herbfield also occurs in patches along stream lines in the Nothofagus cunninghamii scrub below the herbfield.

\section{Short Alpine Herbfield}

Short alpine herbfield is most extensive on Rocky Hill, but even there occupies less than one hectare. It is found mostly on convex deposits on fines below cliffs and along stream lines. The convexity of these deposits is due to the effective trapping of silt and clay particles by the uppermost vegetation where water moves in a sheet

flow. The alpine herbfields are intensively grazed by marsupials which may be responsible for maintaining them as short swards. There is considerable floristic variation related to drainage status, with Ranunculus spp. being most common along the most persistent drainage 1 ines and Acaena montana, Rubus gunnianus and Permettya tasmanica characterizing some of the less constantly soaked situations. Small grasses such as Agrostis parvifiora, Emythranthera

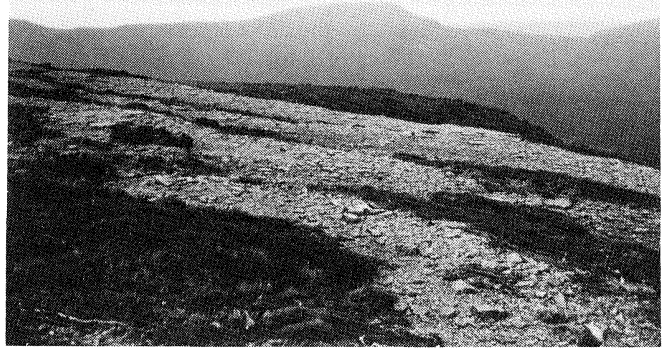

PLATE 1 - Nonsorted stone steps.

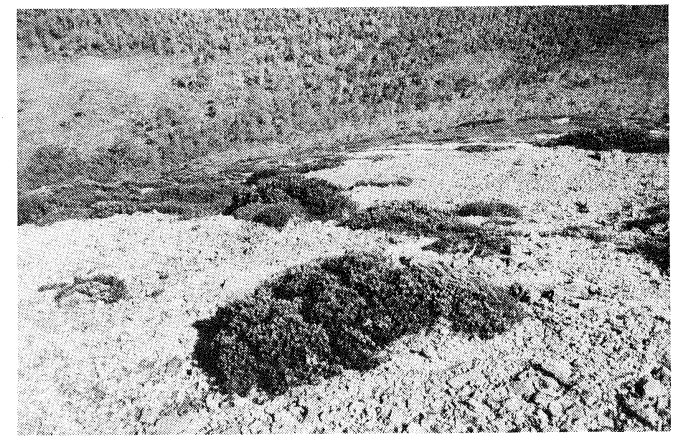

PLATE 2 - Stone stripe riser and tread.

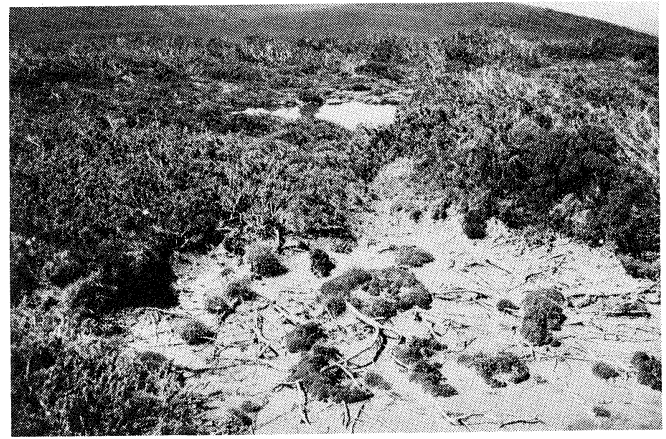

PLATE 3 - Lunette dune to east of an intermittent pool. 
australis and Danthonia pulvinorum are intimately mixed with herbs such as Microseris scapigera, Plantago paradoxa, Epilobium gunnianum, Hypericum japonicum and Colobanthus apetalus. Many of the species recorded for the short alpine herbfields were confined to this vegetation type in the study area (table 1).

A small area of short alpine herbfield was located on the peak of Pyramid Mountain. This contained two species, Helichrysum acuminatum and Drapetes tasmanica that were absent from the Rocky Hill herbfield, and lacked many of the species found at Rocky Hil1, but resembled this latter herbfield in its structure and local species richness. Small areas of the less species-rich Gunnera cordifolia short alpine herbfield were found between Astelia alpina tall alpine herbfield and Athrotaxis cupressoides woodland at Rocky Hill.

\section{Other Alpine Vegetation Types}

Of the alpine vegetation types recognized by Kirkpatrick (1983) only tussock grass1 and and deciduous heath are absent from the study area, and, excluding the communities described above, bolster heath, coniferous heath, heath, tall alpine herbfield and bog communities can all be found.

Bolster heath dominated by Donatia novae-zelandiae is absent from the Pyramid Mountain alpine area but is found on all others within the study area. The bolster plants Abrotanelza forsteroides, Dracophylium minimum, PhylZachne colensoi, Ptemgopappus Zawrencii and Mitrasacme archeri were not observed within the study area, although Carpha rodwayi, Oreobolus pumilio, o. oligocephalus and Ewartia meredithae were present. On the relatively low altitude quartzite, hill D, Donatia novae-zelandiae shares dominance with Gymoschoenus sphaerocephalus. Elsewhere the most abundant associates include Microcachrys tetragona, Empodisma minus and Oreobolus oligocephalus.

On hills A and C Donatia bolster heath is replaced on slightly better drained ground by Diselma archeri coniferous heath. The $D$. archeri bushes are up to $1.8 \mathrm{~m}$ tall and vary from sparse to dense cover. Microcachrys tetragona coniferous heath occurs on all hills and mountains within the study area, being mostly located on shallow soils with gentle slopes. Other alpine heath dominants recorded for the study area are Epacris serpyzzifolia, Baeckea gunniana, Cyathodes dealbata, Pentachondra pumila, Leptospermum mpestre, Richea scoparia and Nothofagus cunninghamii. The latter species forms a metre high heath, with approximately $50 \%$ cover in the dominant stratum, in a belt between $N$. cunninghamii scrub and the higher altitude heath communities.

On the shelves below the upper treeline some poorly drained areas are occupied by bog in which Sphagnum cristatum is ubiquitous and Richea gunnii, Astelia alpina and Carex gaudichaudiana are prominent, or by Astelia alpina tall alpine herbfield.

\section{Other Vegetation}

The numerous cliffs found in the study area support a sparse vegetation characterized by faithful species such as Gnaphalium umbricola and Aristotelia peduncularis. The cliffs are rich in ferns, grasses and soft herbs such as Veronica calycina and Geranium sessiziflorum (table 1).

The subalpine heaths are dominated by MeZaZeuca squamea, which is typically more than $1 \mathrm{~m}$ tall. On the most poorly-drained sites these heaths grade into Gymoschoenus sphaerocephalus tussock sedgeland. With slightly improved drainage they grade into Leptospermum nitidum scrub and forest which, with improved drainage, in turn gives way to Eucalyptus simmondsii open-forest or Eucalyptus subcrenulata woodland over Nothofagus cunninghamii closed-forest.

Eucalyptus coccifera open-scrub, open-forest and woodland forms a narrow altitudinal belt terminating at the upper slope treeline on the western and northern aspects of both mountains where slopes are steep. On the other aspects Nothofagus cunninghamii scrub predominates below the treeline. Athrotaxis cupressoides woodland is confined to two shelves and two, high altitude, south-facing half-basins (plate 4). A few individuals of 


\section{J.B. Kirkpatrick}

A. selaginoides were found in the central A. cupressoides woodland (fig. 3), and only one individual was found in the Pyramid Mountain alpine area.

The one lake in the study area (fig. 3) contained a small area of reed swamp dominated by an unidentified sedge or rush, and in various parts its aquatic vegetation was dominated by Potamogeton australiensis, Isoetes gunnii and MyriophyZlum pedunculatum. A low closed-herbland dominated by Scirpus subtilissimus and Myriophyllum pedunculatum is found at the northern end of the lake where also is found a Richea gunniiSphagnum cristatum bog. A Leptospermum Zanigerum closed-forest occurs on slightly better-drained ground than the bog. A soft organic deposit more than $2 \mathrm{~m}$ deep underlies the bog and the aquatic vegetation near the north and west shores of the lake.

\section{DISCUSSION}

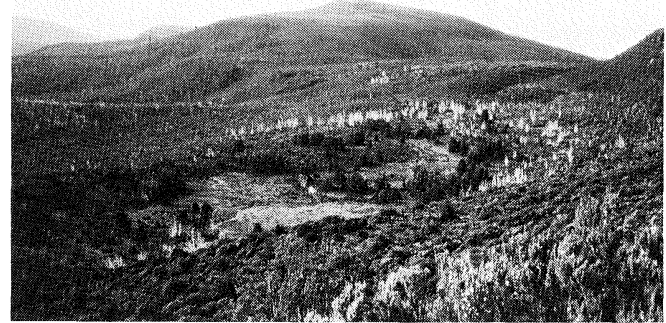

PLATE 4 - Athrotaxis cupressoides woodland mixed with bog on a shelf below Rocky Hill. The boundary of the last fire is marked by tree skeletons. Nothofagus cunninghami scrub occupies the foreground.

The study area contains evidence for at least two major fires, and for a recent period of severe landscape instability. Very little vegetation could have escaped a fire which eliminated Athrotaxis spp. and Diselma archeri from most of the sites suitable for their occurrence. On the southern flanks of the fjaeldmark of hill A a metre-deep gully has been cut through a nonsorted stone step revealing a large Athrotaxis log at an altitude presently bereft of tree growth. Many such buried logs were also revealed by erosion, or found partly protruding from the soil, on the upper terraces of Rocky Hill. The event that killed these trees must have affected almost all of Pyramid Mountain where only one individual of Athrotaxis and no Diselma were found.

A second fire burned most of Rocky Hil1, probably in 1934. This fire further reduced the area occupied by Athrotaxis cupressoides but missed the small remaining areas of Diselma archeri heath, and could not burn the fjaeldmark. An earlier fire almost certainly occurred within the last one or two centuries as many individuals of Nothofagus cunninghamii and Eucalyptus subcrenulata, while large enough to be one or two centuries old, show evidence of being derived from resprouts from the base of older stems. The buried Athrotaxis logs were probably killed by fire as they occur on gentle enough slopes to exclude landslip or avalanche and windthrow does not seem to be common with these species. The Athrotaxis skeletons remain standing for several decades following fire kill, so their burial must be related to a later event. The presence of Athrotaxis logs beneath fjaeldmark cannot be taken as evidence of a warmer climate in the recent past as Athrotaxis survives as a tree at higher altitude on the nearby northeastern spur of Rocky Hill. However, this situation does suggest that an extremely long period without fire preceded the event that killed the now-buried Athrotaxis, as trees as large as that found buried have been shown to be 300 years old in a less exposed environment (Kirkpatrick \& Harwood 1980), and as the occupation of a potential fjaeldmark site by forest would require a long term building up of vegetation shelter to windward.

Nonsorted stone steps and nonsorted stone stripes are associated with the sandstones and mudstones of the Tasmanian high mountains. Outside the study area either or both of these features also occur on Dome Hill, Castle Mountain, High Dome, Last Hil1, Camp Hill, Little Sugarloaf, Goulds Sugarloaf, Mt Rufus, the Boomerang and the Southern Range (fig. 1). The migrating fjaeldmark type is also known from the Boomerang and Mt La Perouse in the Southern Ranges. The proportion of Tasmanian fjaeldmark that could be occupied by other vegetation types in the extremely long term absence of fire is uncertain. In the cases of extremely steep-sided and unstable ridges and poorly drained horizontal pavements even minor disturbance might be sufficient to lead to an accelerating break in plant cover. 
Where shrubs and trees could establish complete cover on steep screes they would tend to accumulate sediment from above, and thus become prone to landslip, a common feature of steep subalpine slopes in Tasmania even where fire has been long absent.

One notable feature of the alpine vegetation of the area burned in the earlier fire is the ubiquity of Microcachrys tetragona, a species among those most susceptible to fire. This ubiquity suggests a means of medium distance dispersal, a means provided by the mountain jay (Strepera fuliginosa) whose cigar-shaped regurgitate contained virtually unmodified sections of the Microcachrys cones in a matrix of Pentachondra pumila fruits in January 1983 throughout the study area.

The partly random nature of survival after fire, and dispersal from surviving individuals, may account for much of the variation observed within and between the vegetation of Tasmanian high mountains, as must the patterning of the dispersal paths available during the Last Glacial. However, despite some noticeable idiosyncracies, the vegetation and flora of Rocky Hill and Pyramid Mountain fit well within the available statewide models, which are based on present environmental conditions.

\section{ACKNOWLEDGEMENTS}

This paper owes a lot to the help in the field given by Tony Moscal. I also thank Terese Hughes and Guus van der Geer for help with the preparation of the manuscript.

\section{REFERENCES}

Barrow, M.D., Costin, A.B. \& Lake, P.S., 1968: Cyclical changes in an Australian fjaeldmark community. J. Ecol., 56: 89-96.

Curtis, W.M., 1963: THE STUDENT'S FLORA OF TASMANIA, PART II. Government Printer, Tasmania.

1967: THE STUDENT'S FLORA OF TASMANIA, PART III. Government Printer, Tasmania.

1979: THE STUDENT'S FLORA OF TASMANIA, PART IVA. Government Printer, Tasmania.

Curtis, W.M. \& Morris, D.I., 1975: THE STUDENT'S FLORA OF TASMANIA, PART I. (2nd Ed.).

\& Stones, M., 1978: THE ENDEMIC FLORA OF TASMANIA. VOLUME VI. Ariel Press, London.

Kirkpatrick, J.B., 1980: Tasmanian high mountain vegetation I - A reconnaissance survey of the Eastern Arthur Range and Mount Picton. Pap. Proc. Roy. Soc. Tasm., 114: $1-20$.

1982: Phytogeographical analysis of Tasmanian alpine floras. J. Biogeogr., $9: 255-271$.

1983: Treeless plant communities of the Tasmanian high country. Proc. Ecol. Soc. Austr., 12: in press.

Kirkpatrick, J.B. \& Harwood, C.E., 1980: Vegetation of an infrequently burned Tasmanian mountain region. Froc. Roy. Soc. Vict., 91: 79-107.

Specht, R.L., 1974: THE VEGETATION OF SOUTH AUSTRALIA. Government Printer, Adelaide. Washburn, A.L., 1979: GEOCRYOLOGY. Arnold, London.

Willis, J.H., 1970: A HANDBOOK TO PLANTS IN VICTORIA, VOLUME I. (2nd Ed.). M.U.P., Melbourne. 


\section{J.B. Kirkpatrick}

TABLE 1

TAXA OBSERVED ON ROCKY HILL AND PYRAMID MOUNTAIN

Alpine

Pyramid Rocky

Mtn Hil
Subalpine

Forest Cliff Herb- Heath/ Aquatic

field scrub

\section{PTERIDOPHYTA}

ASPIDIACEAE

Polystichum proliferum

\section{ASPLENIACEAE}

Asplenium trichomanes

ATHYRIACEAE

Cystopteris fragizis

(L.) Bernb.

\section{BLECHNACEAE}

Blechnum fluviatize

$B$. penna-marina

B. vulcanicum (Bl.) Kuhn

$B$. wattsii Tindale

GLE ICHENIACEAE

Gleichenia alpina

GRAMMI TI DACEAE

Grammitis bizzardieri

HYMENOPHY LLACEAE

Hymenophyzzum peztatum

\section{ISOETACEAE}

Isoetes gunnii

\section{LYCOPODIACEAE}

Huperzia selago

Lycopodium fastigiatum

L. scariosum

\section{GYMNOSPERMAE}

\section{CUPPESSACEAE}

Diselma archeri

\section{PODOCARPACEAE}

Microcachrys tetragona

Phyzlocladus asplenitfolius

Podocarpus Zowrencii

TAXODIACEAE

Athrotaxis cupressoides

A. selaginoides

ANGIOSPERMAE

MONOCOTYLEDONEAE

CENTROLEPIDACEAE

Centrolepis monogyna

c. muscoides 


\begin{tabular}{|c|c|c|c|c|c|c|c|}
\hline & Alpi & & & & Subalp & ine & \\
\hline & $\begin{array}{c}\text { Pyramid } \\
\text { Mtn }\end{array}$ & $\begin{array}{l}\text { Rocky } \\
\text { Hil11 }\end{array}$ & Forest & Cliff & $\begin{array}{l}\text { Herb- } \\
\text { field }\end{array}$ & $\begin{array}{l}\text { Heath/ } \\
\text { scrub }\end{array}$ & Aquatic \\
\hline CYPERACEAE & & & & & & & \\
\hline Carex appressa & & & $\mathrm{x}$ & - & - & $\mathrm{x}$ & - \\
\hline C. gaudichaudiana & & $\mathrm{x}$ & & & & & \\
\hline Carpha alpina & $\mathrm{x}$ & $\mathrm{x}$ & $\mathrm{x}$ & & & $\mathrm{x}$ & \\
\hline C. curvata W.M. Curtis ined. & & $\mathrm{x}$ & & & & & \\
\hline $\begin{array}{l}\text { C. rodwayi w.M. Curtis ined. } \\
\text { Gahnia grandis }\end{array}$ & $\mathrm{x}$ & $\mathrm{x}$ & & & & & \\
\hline Gymoschoenus sphaerocephatus & & & $\mathrm{x}$ & & & $\mathrm{x}$ & \\
\hline Lepidosperma fiziforme & & $\mathrm{x}$ & & & & $\mathrm{x}$ & \\
\hline L. Zineare var. inops & $\mathrm{x}$ & $\mathrm{x}$ & & & & & \\
\hline oreobolus acutifolius & $\mathrm{x}$ & $\mathrm{x}$ & & & & & \\
\hline O. oligocephaZus W.M. Curtis ined. & $\mathrm{x}$ & $\mathrm{x}$ & & & & & \\
\hline O. pumizo & $\mathrm{x}$ & $\mathrm{x}$ & & & & & \\
\hline Schoenus calyptratus & $\mathrm{x}$ & $\mathrm{x}$ & & & & & \\
\hline Scimpus aucklandicus & & $\mathrm{x}$ & $\mathrm{x}$ & - & $\mathrm{x}$ & $\mathrm{x}$ & \\
\hline S. fluitans & & & & & & & $\mathrm{x}$ \\
\hline S. subtizissimus & & & & & & $\mathrm{x}$ & \\
\hline$S$. sp. & & & & & & & $\mathrm{x}$ \\
\hline Uncinia compacta R.Br. & $\mathrm{x}$ & $\mathrm{x}$ & & & & & \\
\hline U. flaccida & $\mathrm{x}$ & & & $\mathrm{x}$ & & & \\
\hline U. tenelza & & & $\mathrm{x}$ & & & & \\
\hline HYPOXI DACEAE & & & & & & & \\
\hline Campynema Zineare & $\mathrm{x}$ & $\mathrm{x}$ & & & & & \\
\hline IRIDACEAE & & & & & & & \\
\hline Diplarrhena Zatifolia & $x$ & $\mathrm{x}$ & $\mathrm{x}$ & - & - & $x$ & - \\
\hline Isophysis tasmanica & & $x$ & & & & & \\
\hline JUNCACEAE & & & & & & & \\
\hline Juncus antarcticus & $\mathrm{x}$ & $\mathrm{x}$ & - & - & $\mathrm{x}$ & - & - \\
\hline$J \cdot \mathrm{sp} \cdot 1$ & & & $\mathrm{x}$ & & & & \\
\hline J. sp. 2 & & & & $\mathrm{x}$ & & & \\
\hline Luzula spp. & $\mathrm{x}$ & $\mathrm{x}$ & - & $x$ & $\mathrm{x}$ & - & - \\
\hline LILIACEAE & & & & & & & \\
\hline Astelia alpina & $\mathrm{x}$ & $x$ & $\mathrm{x}$ & & & $\mathrm{x}$ & \\
\hline Blandfordia punicea & $\mathrm{x}$ & $\mathrm{x}$ & $\mathrm{x}$ & & & $\mathrm{x}$ & \\
\hline Libertia pulchelza & & & & $x$ & & & \\
\hline Milzigania densiflora & $\mathrm{x}$ & $\mathrm{x}$ & & $\mathrm{x}$ & & & \\
\hline ORCHIDACEAE & & & & & & & \\
\hline Prasophyzzum alpinum & $x$ & $\mathrm{x}$ & & & & & \\
\hline Pterostyzis dubia & $\mathrm{x}$ & $x$ & & $\mathrm{x}$ & & & \\
\hline Thelymitra sp. & & $\mathrm{x}$ & & & & & \\
\hline POACEAE & & & & & & & \\
\hline Agrostis aemula & & & & $\mathrm{x}$ & & & \\
\hline A. parviflora & & & & & $\mathrm{x}$ & & \\
\hline A. venusta & $\mathrm{x}$ & $\mathrm{x}$ & & $\mathrm{x}$ & $x$ & & \\
\hline Danthonia fortunae-hibernae & & & $\mathrm{x}$ & $\mathrm{x}$ & & $\mathrm{x}$ & \\
\hline D. nivicola & $\mathrm{x}$ & $\mathrm{x}$ & & & & & \\
\hline D. pauciflora & $x$ & $x$ & & & $\mathrm{x}$ & & \\
\hline D. puZvinorum D.I. Morris & & & & & $\mathrm{x}$ & & \\
\hline Deyeuxia carinata & $\mathrm{x}$ & $\mathrm{x}$ & & $\mathrm{x}$ & & & \\
\hline D. monticola & $\mathrm{x}$ & $\mathrm{x}$ & & $\mathrm{x}$ & & $\mathrm{x}$ & \\
\hline D. sp. & $x$ & $\mathrm{x}$ & & $x$ & & & \\
\hline
\end{tabular}




\section{J.B. Kirkpatrick}

15
Alpine

Pyramid Rock

Mtn

Hi11

rythranthera australi

(Petrie) Zotov

Hierochtoe fraseri

$H$. redolens

Microlaena tasmanica

Poa gunnii

P. Zabizzardieri Steud.

P. saxicola

POTAMOGETONACEAE

Potamogeton australiensis

\section{RESTIONACEAE}

Calorophus elongatus

Empodisma minus (Hook. F.)

Johnson \& Cutler

Restio complanatus

\section{XYRIDACEAE}

Xyris marginata

DICOTYLEDONAE

APIACEAE

Actinotus bellidioides

A. moorei

A. suffocata

Dichosciaduem ranunculaceum

Diplaspis hydrocotyle

Hydrocotyle sibthorpioides

oreomyrrhis ciliata

\section{ASTERACEAE}

Abrotanezza scapigera

Brachycome tenuiscapa

Celmisia Zongifolia

Cotula alpina

Erigeron pappachroma

E. stezzatus

Ewartia meredithae

E. planchonii

Gnaphalium traversii

C. umbricola

HeZichrysum acuminatum

H. backhousii

H. Zedifolium

H. milliganii

H. scorpioides

Lagenifera stipitata

Microseris scapigera

Olearia ledifolia

o. persoonioides

o. phlogopappa

- pinifolia

Senecio gunni

S. Zeptocarpus

S. pectinatus

$\mathrm{x}$

$\mathrm{x}$
H. pumizum
Subalpine

Forest Cliff Herb- Heath/ Aquatic

field scrub $x$ $\mathrm{x}$

$\mathrm{x}$

$\mathrm{x}$

$\mathrm{x}$

x

(1)




$$
\text { Alpine }
$$

Pyramid Rocky Mtn Hill
Subalpine

Forest Cliff Herb- Heath/ Aquatic

BORAGINACEAE

Mysotis australis

\section{BRASS ICACEAE}

Cardamine sp.

\section{CAMP ANULACEAE}

Wahlenbergia saxicola

\section{CARYOPHY LLACEAE}

Colobanthus apetazus

\section{CUNONI ACEAE}

Anodopetalum bigzandulosum

Bauera mibioides

\section{LLENIACEAE}

Hibbertia procumbens

\section{DONATIACEAE}

Donatia novae-zelandiae

\section{DROSERACEAE}

Drosera arcturi

D. pygmaea

\section{ELAEOCARPACEAE}

Aristotelia peduncularis

\section{EPACRIDACEAE}

Archeria eriocarpa

A. hirtelza

A. serpyzzifolia

Cyathodes dealbata

C. parvifolia

C. petiolaris

C. straminea

Epacris sempyzifolia

Lissanthe montana

Monotoca sp. aff. Zinifolia

M. submutica

Pentachondra pumiza

Prionotes cerinthoides

Richea gunnii

R. pandanifolia

R. scoparia

$R$. sprengelioides

Sprengelia incamata

Trochocarpa cunninghamii

T. gunni

\section{ERICACEAE}

Galtheria hispida

Pemettya tasmanica 


\section{J.B. Kirkpatrick}

\section{Alpine}

$\begin{array}{clrl}\begin{array}{c}\text { Pyramid } \\ \text { Mtn }\end{array} & \text { Rocky } & \text { Forest } & \text { Cliff } \begin{array}{l}\text { Herb- Heath/ Aquatic } \\ \text { field scrub }\end{array}\end{array}$

ESCALLONIACEAE

Anopterus glandulosus

Tetracarpaea tasmanica

EUCRYPHIACEAE

Eucryphia Zucida

E. mizziganii

FABACEAE

Oxylobium elzipticum

FAGACEAE

Nothofagus cunninghamii

GENTI ANACEAE

Gentianella diemensis

\section{GERANIACEAE}

Geranium potentizzoides

G. sessiziflorum

\section{HALORAGACEAE}

Gonocarpus micranthus Thunb.

G. montanus (Hook. f.)

Orchard

Gunnera cordifolia

Myriophyzzum pedunculatum

HYPERICACEAE

Hypericum japonicum

LOGANIACEAE

Mitrasacme montana

\section{MYRTACEAE}

Baeckea gunniona

Eucalyptus coccifera

E. simmondsii Maiden

E. subcrenulata

E. vermicosa

Leptospermum Zanigemum

L. nitidum

L. mpestre

Melaleuca squamea

\section{ONAGRACEAE}

EpiZobium gunnianum

E. tasmanicum

\section{OXALIDACEAE}

Oxalis Zactea

PLANTAGINACEAE

Plantago daztoni

P. paradoxa

P. tasmanica

$\begin{array}{lll} & x \\ x & x\end{array}$

$x$
$x$

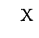

$\mathrm{x}$

x $\quad x$

$\mathrm{x}$

$\mathrm{x} \quad \mathrm{x}$

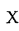

$\mathrm{x}$

$x$

$\mathrm{x}$

$\mathrm{X}$

$\mathrm{x}$

$\mathrm{x}$

$\mathrm{x}$ 
Rocky Hill and Pyramid Mountain Vegetation

\begin{tabular}{clrl}
\multicolumn{2}{c}{ Alpine } & \multicolumn{2}{c}{ Subalpine } \\
$\begin{array}{c}\text { Pyramid } \\
\text { Mtn }\end{array}$ & Hill & Forest & Cliff $\begin{array}{l}\text { Herb- Heath/ Aquatic } \\
\text { field scrub }\end{array}$
\end{tabular}

\section{PROTEACEAE}

Agastachys odorata Bellendena montana Lomatia polymorpha orites acicularis

o. diversifolia

o. milziganii

o. revoluta

Persoonia gunnii

Persoonia sp.

TeZopea truncata

\section{RANUNCULACEAE}

Anemone crassifolia

Ranunculus collinus

$R$. decurvus

R. grabrifolius

$R$. nanus

R. tripzodontus

ROSACEAE

Acaena montana

A. novae-zelandiae

Rubus gunnianus

RUB I ACEAE

Coprosma moorei

C. nitida

C. pumila

Galium ciliare

RUTACEAE

Boronia citriodora

\section{SANTALACEAE}

Exocarpos humifusus

Leptomeria glomerata

$x \quad x \quad x$

$x$

$\mathrm{x}$

$\mathrm{x}$

$\mathrm{x}$

SCROPHULARIACEAE

Euphrasia gibbsiae

E. striata

Ourisia integrifolia

Veronica calycina

\section{STYLIDIACEAE}

Styzidium graminifolium

\section{THYMELACEAE}

Drapetes tasmanica Pimelea lindleyana

TREMANDRACEAE

Tetratheca procumbens

VIOLACEAE

Viola hederacea

\section{WINTERACEAE}

Drimys Zanceolata 
TABLE 2

SPECIES ASSOCIATION IN THE ALPINE VEGETATION

Coprosma nitida

Deyeuxia monticola

Dichosciadeum ronunculaceum

Plantago tasmanica

Drapetes tasmanica

Senecio leptocarpus

Richea sprengelioides

Senecio pectinatus

Exocarpos humifusus

Helichrysum backhousi

Bellendena montana

Orites revoluta.

Olearia ledifolia

Epacris serpyllifolia

Poa gunnii

Euphrasia striata

hondra pumila

Helichrysum milligani

Leptospermum mupestre

Gonocarpus montanus

Campynema lineare

Gentianella diemensis

Astelia alpina

Microcachrys tetragona

Cyathodes dealbata

Carpha alpina

Mitrasacme montan

Oreobolus oligocephalus

oreobolus acutifolius

$\begin{array}{lllllllllllllll}\text { P2 } & \text { P6 P7 P3 P5 P8 P1 } & \text { P9 P10 } & \text { P4 P18 } & \text { R7 } & \text { R4 P20 P12 } & \text { R3 P11 P14 P15 P16 P17 } & \text { R8 } & \text { R1 R2 } & \text { R5 P21 R6 P13 P19 }\end{array}$

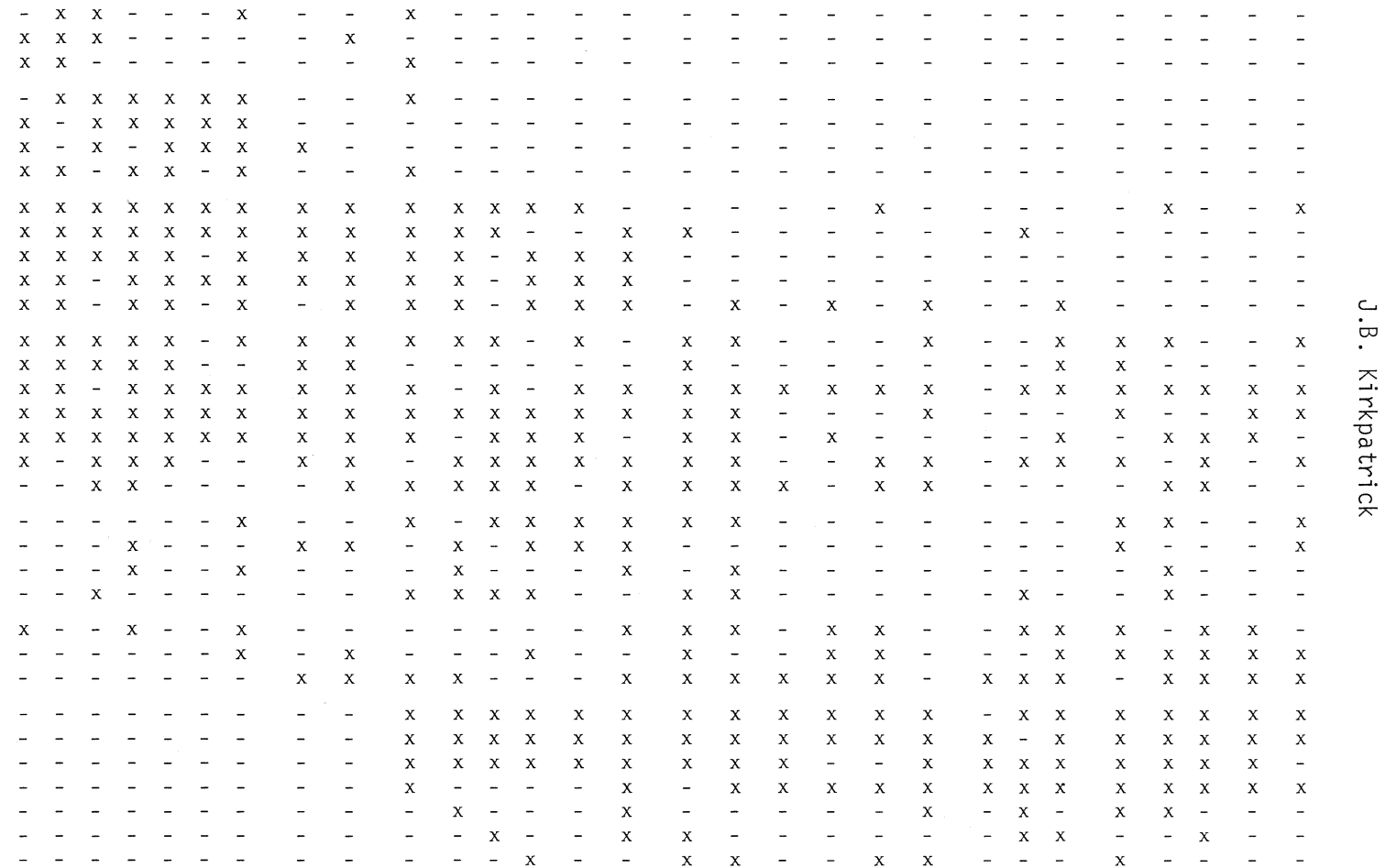


TABLE 2 cont

SPECIES ASSOCIATION IN THE ALPINE VEGETATION

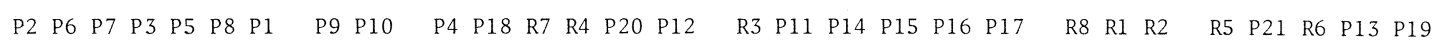

Ewartia meredithae Sprengelia incarmata Baeckea gunniana Danthonia pauciflora

Drosera arcturi

Gleichenia alpina Microlaena tasmanica Donatia novae-zelandiae Anemone crassifolia

Lycopodium scariosum Uncinia compacta Drimys lanceolata

Diplarrhena latifolia

Monotoca aff. Iinifolia Celmisia longifolia

ADDITIONAL SPECIES:

Actinotus moorei R2, R5; Archeria serpyllifolia R5; Athrotaxis selaginoides R5; Blechnum penna-marina P8; Carpha rodwayi R1, R2; Celmisia longifolia P1, R3; Coprosma moorei P16, P17; Cyathodes petiolaris P16, R7; Diselma archeri R2, R6; Erigeron pappachroma P9; Euphrasia gibbsiae R1; Gaultheria hispida R4; Gnaphalium traversii P8;

P10 P13; Hydrocotyle sibthomioides P8; Ieptomeria glomerata R1. Iissanthe montana P8. Luzu7a spp. P1 Praseri

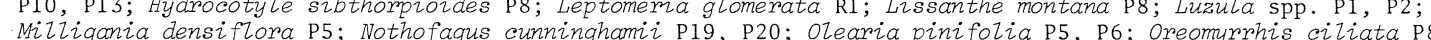
Orites acicularis P1, P11. Pemettya tasmenica P7, P8. Phyllocladus aspleniifolius P20; Restio complanatus R8; Rubus gunnianus P8; Schoenus calyptratus R3; Stylidium graminifolium P17, R8; Viola hederacea P8. 